\title{
FENOMENA KAWIN KONTRAK DI KAWASAN PUNCAK BOGOR
}

\author{
Siti Sarah Maripah \\ Badan Ekonomi Kreatif Jakarta \\ Email: sitisaraharra@gmail.com
}

\begin{abstract}
Marriage is a bond which is carried by a pair of human who love each other. Marriage was also accompanied by good purpose and must be complete certain requirements in order to be legally in law and religion. In fact, occurred a phenomenon that makes the practice of marriage as deviant behavior. The phenomenon is a marriage between Middle Eastern Tourist with a local woman accompanied agreements specified period or so-called marriage contract in Puncak Bogor West Java. This research will describe an explain the phenomenon of marriage contract from the standpoint of social deviation. This research used a qualitative approach and descriptive study method. These research and method are used to obtain the conclusion from some information and data acquired about phenomenon of marriage contract. Data collection techniques in this research use indepth interviews, observasion, and documentation. Based on the result of research on the perpetratos of marriage contract and village community, middle eastern tourist arranged marriage contract to get the biological needs, and a local woman arranged a marriage contract to suficient the economic needs. This marriage contract have so many impact on various aspects of economic, social cultural and psychological for women. Marriage contract belongs to the social deviation, because the implementation is not accordance with religion dan law. This phenomenon still continues until now, but it is more closed. Marriage contract occurred with the support by the local tourism movers are involved in the process of the marriage contract.

Keywords: Middle Eastern Tourist, Marriage contract, Social Deviation
\end{abstract}

\section{ABSTRAK}

Fenomena tersebut adalah perkawinan antara turis-turis asal Timur Tengah dengan wanita lokal dengan perjanjian jangka waktu tertentu, atau disebut kawin kontrak yang berada di Puncak Bogor Jawa Barat. Penelitian ini bertujuan untuk memperoleh gambaran secara menyeluruh bagaimana fenomena kawin kontrak di Desa Tugu Selatan Kecamatan Cisarua Kabupaten Bogor. Penelitian ini menggunakan 
pendekatan kualitatif dan metode penelitian studi deskriptif, dengan teknik pengumpulan data yaitu wawancara, observasi dan dokumentasi. Berdasarkan hasil penelitian terhadap pelaku kawin kontrak dan masyarakat, kawin kontrak ini dilakukan turis-turis Timur Tengah untuk memenuhi kebutuhan biologis mereka, sedangkan wanita lokal yang melakukan kawin kontrak didasari adanya tuntutan kebutuhan ekonomi. Kawin kontrak ini menimbulkan dampak dari berbagai aspek yang lebih dirasakan oleh pelaku wanita, yaitu dampak ekonomi, sosial budaya dan psikologis. Praktek kawin kontrak ini juga terjadi karena dukungan para penggerak pariwisata setempat yang ikut terlibat dalam proses pelaksanaan kawin kontrak tersebut.

Kata Kunci: Turis Timur Tengah, Kawin Kontrak, Penyimpangan Sosial.

\section{PENDAHULUAN}

Perkawinan merupakan ikatan lahir batin antara seorang pria dengan seorang wanita sebagai suami isteri yang bertujuan untuk membentuk keluarga (rumah tangga) yang bahagia dan kekal berdasarkan Ketuhanan Yang Maha Esa.

Dari pengertian perkawinan di atas dapat diketahui beberapa tujuan perkawinan: (1) untuk memperoleh kehidupan sakinah yang dilandasi mawaddah dan rahmah, (2) untuk regenerasi/reproduksi, (3) tujuan perkawinan adalah untuk pemenuhan kebutuhan biologis, (4) untuk menjaga kehormatan, dan (5) untuk ibadah.3 Berkaitan dengan urgensi perkawinan tersebut, Rasulullah saw sangat menganjurkan pernikahan terutama bagi mereka yang sudah memiliki kemampuan lahir dan batin. Namun pada saat ini di kawasan Cisarua Puncak terjadi suatu fenomena yang disebut dengan fenomena kawin kontrak. Kawin kontrak atau Nikah mut"ah pernah diizinkan Nabi saat terjadi peperangan. Para sahabat saat itu dalam kondisi membujang dan meninggalkan isteri mereka, namun saat ini kawin kontrak atau nikah mut'ah sudah diharmkan bagi Agama Islam. Allah SWT juga berfirman yang artinya; "...dan telah dimaklumi bersama bahwa wanita yang dinikahi secara mut'ah tidaklah tergolong budak dan tidak pula disebut sebagai isteri karena tidak adanya aturan-aturan yang lazim sebagaimana seorang isteri layaknya seperti: waris, iddah, thalaq dan nafkah". Berdasarkan firman Allah SWT tersebut, memang benar bahwa wanita yang melakukan kawin kontrak tidak memiliki hak atas hal-hal tersebut, maka akan menimbulkan dampak pada wanita tersebut jika ia sampai mempunyai anak. Kawin kontrak ini juga tidak semata-mata terjadi begitu saja melainkan ada asal mula mengapa bisa muncul fenomena ini di daerah Puncak. Wanita-wanita pelaku kawin kontrak tersebut bukan berasal dari Cisarua atau Bogor melainkan dari Cianjur, Sukabumi dan daerah-daerah lain. Wanita-wanita tersebut biasanya menetap tidak jauh 
dari tempat tinggal atau kawasasan yang dipenuhi wisatawan Arab salah satunya adalah kawasan Desa Tugu Selatan atau kawasan Warung Kaleng Kecamatan Cisarua Kabupaten Bogor. Wanita-wanita itu berani melakukan hal tersebut tentu karena didasari oleh kebutuhan ekonomi. mengkaji fenomena kawin kontrak ini sebagai hal yang menyimpang dari Agama dan kaidah hukum Undang-Undang No.1 Tahun 1974 tentang perkawinan. Dalam masyarakat berarti praktek kawin kontrak ini termasuk dalam suatu hal yang menyimpang, atau disebut sebagai penyimpangan sosial.

Latar belakang masalah di atas menarik perhatian peneliti untuk mengungkapkan secara menyeluruh mengenai fenomena kawin kontrak. Oleh sebab itu peneliti tertarik ingin meneliti secara lebih mendalam mengenai fenomena kawin kontrak tersebut, maka peneliti mengangkat judul "Fenomena Kawin Kontrak di Kawasan Puncak Bogor Jawa Barat (Studi Deskriptif pada Pelaku Kawin Kontrak di Desa Tugu Selatan Kecamatan Cisarua Kabupaten Bogor)".

\section{METODE}

Penelitian ini dilakukan dengan menggunakan pendekatan kualitatif dengan metode studi deksriptif. Pendekatan ini digunakan untuk mendeskripsikan fenomena kawin kontrak di kawasan Puncak Bogor. Penelitian ini bertujuan untuk menganalisis bagaimana fenomena kawin kontrak tersebut. Data yang didapat kemudian direduksi dan dianalisis sehingga menghasilkan datadata yang spesifik berdasarkan hasil wawancara mendalam, observasi pasrtisipati pasif, dan studi dokumentasi. Data yang dianalisis terfokus pada beberapa rumusan masalah yakni latar belakang munculnya Kampung Arab sehingga muncul kawin kontrak, pandangan pelaku kawin kontrak terhadap pernikahan, faktor pendorong pelaku melakukan kawin kontrak, proses pelaksanaan kawin kontrak, konsekuensi pemenuhan kewajiban suami isteri bagi pelaku kawin kontrak, dampak kawin kontrak bagi pelaku dan pandangan masyarakat terhadap fenomena kawin kontrak.

Informan dalam penelitian ini berjumlah 13 orang yang tergolong dalam 4 informan pokok yaitu pelaku kawin terdiri dari 2 wanita tuna susila lokal dan 2 laki-laki Timur Tengah. dan 9 lainnya sebagai informan pendukung yaitu masyarakat yang terdiri dari ketua komunitas, aparat desa, masyarakat biasa, ketua ormas dan ketua RT/RW.

Teknik pengumpulan data yang digunakan oleh peneliti meliputi wawancara mendalam, observasi partisipatif, dan studi dokumentasi. Uji keabsahan data dilakukan dengan triangulasi dan membercheck berdasarkan sumber data. Teknik analisis data menggunakan data reduksi (data reduction), penyajian data (display data) dan kesimpulan (conclusion drawing verification).

HASIL DAN PEMBAHASAN 


\section{Latar Belakang Munculnya Kampung Arab Sehingga Terjadi Fenomena Kawin Kontrak}

Kampung Arab yang berada di kawasan Warung Kaleng yang letaknya berada di sekitar wilayah Desa Tugu Selatan dan Tugu Utara ini mulai didatangi oleh orang Timur Tengah pada tahun 1980an. Keberadaannya diawali dengan cerita mengapa ada kawasan yang disebut sebagai "Warung Kaleng" pada tahun 1980an. Yaitu karena terdapat beberapa warung yang terbuat dari kaleng drum milik orang Arab, dan pada tahun tersebut pula orang-orang Arab tersebut mulai membawa kerabat, teman, dan suadara mereka untuk datang ke Puncak. Kawasan Puncak memang dipenuhi oleh villa-villa, hotel dan penginapan untuk para wisatawan domestik hingga wisatawan Timur Tengah.

Selain banyaknya fasilitas seperti villa dan restaurant Timur Tengah di Puncak, tersedianya pelayanan jasa bagi para wisatawan Timur Tengah juga menjadi daya tarik tersendiri bagi orang-orang Arab untuk datang ke kawasan Puncak khusunya Kampung Arab. Pelayanan jasa yang tersedia meliputi; sawag atau pemandu, driver taksi, driver ojek, chef, penyedia villa, dan security. Para penyedia jasa ini lebih senang dengan sebutan-sebutan asing tersebut, mereka menganggap itu lebih keren untuk didengar. Mereka semua tergabung dalam komunitasnya masing-masing, di mana komunitas mereka semua berada dalam naungan Komunitas Penggerak Pariwisata (kompepar). Para pekerja pariwisata ini merupakan warga asli yang tinggal di kawasan Puncak. Mereka selalu siap untuk melayani para tamu Timur Tengah yang berada di kawasan Puncak, termasuk dalam jasa menyediakan hiburan malam hingga hiburan seksual.

Seiring dengan terus bertambahnya jumlah wisatwan Timur Tengah ke kawasan Puncak, pada tahun 1987 mulai terdengar istilah "kawin kontrak" antara laki-laki Timur Tengah dengan wanita lokal. Berawal dari adanya oknum orang Timur Tengah yang datang dan melakukan kawin kontrak atau nikah mut'ah dengan wanita setempat. Kawin kontrak atau nikah mut'ah adalah perkawinan yang dilakukan dalam jangka waktu tertentu atau hanya sementara, setelah jangka waktu perkawinan itu berakhir maka hubungan perkawinan mereka sudah berakhir. Seperti yang dikatakan oleh Faisal (2008) bahwa:

Menurut istilah, definisi umum yang mungkin bisa mencakup arti mut'ah yang dimaksudkan oleh para ulama adalah: Akad yang dilakukan oleh seorang laki-laki untuk menikahi seorang perempuan dalam jangka waktu sehari, seminggu atau sebulan atau seorang ditentukan (disepakati) seperti sebulan, dua bulan, satu hari, dua hari dan kemudian laki-laki itu meninggalkannya setelah masa yang ditentukan itu habis. (hlm. 38)

Kawin kontrak yang sudah ada sejak 28 tahun yang lalu ini sempat menjadi sangat terkenal hingga Mancanegara khususnya ke Negara-Negara Timur 
Tengah. Dulu wanita yang melakukan kawin kontrak adalah gadis-gadis setempat yang biasanya dipaksa oleh keluarga mereka untuk menikah dengan orang Arab dengan alasan kebutuhan ekonomi. Lain halnya dengan sekarang, sekarang wanita yang melakukan kawin kontrak bukanlah gadis-gadis setempat, melainkan adalah wanita-wanita tuna susila yang sering menjajakan diri mereka pada turis Arab di kawasan Puncak. Keberadaanya sempat sangkat memuncak pada tahun 20072008 namun memasuki tahun 2010 kawin kontrak tersebut menuai banyak protes sehingga hingga saat ini keberadaannya menjadi tertutup. Hasil penelitian ini menunjukkan bahwa ada oknum-oknum yang sebenarnya sampai saat ini masih terlibat dalam kawin kontrak namun berusaha menutupi keberadaan kawin kontrak tersebut untuk menjaga nama baik wisatawan Timur Tengah dan daerah Puncak itu sendiri, karena orang-orang ini juga yang bekerja dan terlibat dalam proses kawin kontrak. Keberadaan wisatawan Timur Tengah memang telah menghidupkan segala aspek dalam bidang pariwisata dan memberikan banyak keuntungan bagi masyarakat setempat maupun bagi lingkungan setempat. Hal ini dikatakan buruk karena menyalahi nilai-nilai yang ada di masyarakat, seperti yang diungkapkan Setiadi dan Kolip (2011, hlm.187) yang menyatakan bahwa "perilaku menyimpang adalah perilaku dari para warga masyarakat yang dianggap tidak sesuai dengan kebiasaan, tata aturan atau norma sosial yang berlaku." mereka melakukan tindakan yang tidak sesuai dengan norma masyarakat tempat di mana mereka berada, di mana di kawasan Puncak mayoritas masyarakatnya adalah muslim.

\section{Pandangan Pelaku Kawin Kontrak di Desa Tugu Selatan Kecamatan Cisarua Kabupaten Bogor terhadap Pernikahan}

\section{a. Pandangan pelaku wanita}

Pandangan mereka terhadap pernikahan yang sesungguhnya tidak melenceng dari Undang-Undang, yaitu dalam pasal 1 Undang-Undang Nomor 1 tahun 1974 yang mengatakan bahwa "perkawinan ialah ikatan lahir batin antara seorang pria dengan seorang wanita sebagai suami isteri dengan tujuan membentuk keluarga (rumah tangga) yang bahagia dan kekal berdasarkan ketuhanan yang Maha Esa". Walaupun mereka adalah seorang wanita tuna suila yang sering melakukan kawin kontrak, namun tidak merubah pandangan mereka dalam menilai apa itu pernikahan yang sesungguhnya.

Menurut informan pernikahan juga dianggap sesuatu yang wajib dilakukan karena merupakan penyempurna separuh Agama dalam diri seseorang. Pendapat tersebut juga sama sekali tidaklah salah. Hadikusuma (2007) menegaskan bahwa:

Jadi perkawinan dalam arti 'ikatan Jasmani dan rohani' berarti suatu ikatan untuk mewujudkan kehidupan yang selamat bukan saja di dunia tetapi juga di akhirat, bukan saja lahiriah tetapi juga 
batiniyah, bukan saja gerak langkah yang sama dalam karya tetapi juga gerak langkah yang sama dalam berdo'a. sehingga kehidupan dalam keluarga rumah tangga itu rukun dan damai, dikarenakan suami dan isteri serta anggota keluarga berjalan seiring bersama pada arah dan tujuan yang sama. (hlm. 10)

Berdasarkan pendapat di atas, maka peneliti merasa mengenai apa yang dikatakan oleh informan bahwa perkawinan merupakan suatu proses penyempurnaan Agama adalah benar, karena suatu perkawinan yang baik seharusnya mewujudkan kehidupan lahiriyah tetapi juga batiniyah yang membawa pasangan suami dan isteri pada kebaikan dan pahala, dan suami menjadi ladang pahala bagi isteri, hubungan yang mereka lakukan menjadi suatu pahala dan sunah yang dilaksanakan sehingga mereka dapat mewujudkan keluarga yang damai dan sejahtera.

\section{b. Pandangan Pelaku laki-laki}

Adapun pandangan menurut informan laki-laki yaitu orang Timur Tengah, mereka lebih menganggap suatu perkawinan adalah sebuah perjanjian yang dilakukan melalui ijab kabul, perjanjian tersebut adalah perjanjian untuk hidup bersama antara calon suami dan calon isteri. Anggapan tersebut sesuai dengan perkawinan yang dilihat secara khusus dari hukum Agama Islam, Hadikusuma (2007) yang menjelaskan bahwa:

Menurut hukum Islam perkawinan adalah 'akad' (perikatan) antara wali wanita calon isteri dengan pria calon suaminya. Akad nikah itu harus diucapkan oleh wali si wanita dengan jelas berupa ijab (serah) dan diterima (Kabul) oleh si calon suami yang dilaksanakan di hadapan dua orang saksi yang memenuhi syarat. (hlm. 10-11)

Yang dimaksud oleh informan adalah ijab kabul yang juga dilakukan antara wali dengan calon suami di hadapan saksi. Perkawinan memang suatu ikatan yang harus dilakukan melalui akad atau ijab kabul. Pandangan tersebut sesuai dengan hukum Islam, karena seluruh informan yang merupakan pelaku kawin kontrak adalah muslim. Berdasarkan hasil penelitian bahwa kawin kontrak yang mereka lakukan tidak mempengaruhi pandangan atau persepsi mereka mengenai arti pernikahan yang sesungguhnya.

Faktor Pendorong Pelaku Melakukan Kawin Kontrak di Desa Tugu Selatan Kecamatan Cisarua Kabupaten Bogor

\section{a. Faktor wanita melakukan kawin kontrak \\ Dalam fenomena kawin kontrak} ini, peneliti menemukan banyak faktor baik faktor internal maupun faktor eksternal yang bisa dianalisis mengapa para wanita lokal dan laki-laki Timur Tengah melakukan kawin kontrak. Berdasarkan hasil penelitian faktor yang menyebabkan wanita melakukan kawin kontrak yaitu Rendahnya tingkat pendidikan, Rendahnya tingkat ekonomi kehidupan wanita pelaku kawin kontrak serta-merta telah membuat mereka juga tidak bisa merasakan pendidikan yang layak. 
Mereka hanya lulusan SD yang tidak melanjutkan pendidikan mereka ke jenjang berikutnya. Karena mereka hanyalah lulusan SD, mereka berpikir bahwa mereka tidak memiliki keahlian apapun sehingga mereka lebih tertarik melakukan perilaku menyimpang. mereka melakukan penyimpangan yang mereka sendiri sadari bukan hal yang baik dan akan membawa damak buruk pada mereka. Menurut Setiadi dan Kolip (2011, hlm. 193) salah satu bentuk penyimpangan yaitu "penyimpangan negatif adalah kecenderungan bertindak ke arah nilainilai sosial yang dipandang rendah dan akibatnya selalu buruk. Faktor selanjutnya yaitu rendahnya kesadaran akan penyakit HIV AIDS, rendahnya tingkat keimanan yang mereka miliki. Berdasarkan hasil penelitian, faktor ekonomi merupakan faktor eksternal yang utama yang menjadikan wanitawanita lokal tersebut mau menjadi wanita tuna susila (WTS) bahkan mau menikah secara kontrak. Seperti yang dikatakan Anwar (2010, hlm. 355) bahwa alasan wanita menjadi pelaku prostitusi adalah: "karena tekanan ekonomi, seseorang tanpa pekerjaan tentunya akan tidak memperoleh penghasilan untuk nafkahnya. Maka terpaksalah mereka untuk hidup menjual diri sendiri dengan cara dan jalan yang paling mudah. Selain faktor ekonomi yang utama adapula faktor eksternal seperti kurangnya pengawasan dan kasih sayang dari keluarga, sudah terjerumus dalam pergaulan bebas sebelumnya, ajakan teman, lokasi Puncak yang strategis tidak jauh dari tempat tinggal mereka, dan gaya hidup sebagai WTS yang harus membutuhkan modal. Faktor utama laki-laki Timur Tengah melakukan kawin kontrak Kondisi geografis ini memang hal yang paling diincar oleh wisatawan, baik wisatawan domestik maupun wisatawan asing. Mereka yang biasa berada di daerah yang panas tentu akan merasa suka ketika berada di tempat yang dingin, sesuai dengan pernyataan Umanah dkk (2015) dalam jurnalnya yang mengatakan bahwa:

Since then the area has been called as Warung Kaleng by the local community. The Arab tourist chose this area to spend their holiday because those tourist from the Middle Eastern yearned very much for a different atmosphere from their own country which is too hot. (hlm. 143).

Mereka merasakan udara dan suasana yang berbeda yang membuat mereka ingin melakukan hal-hal lain ketika berlibur.

\section{Proses Pelaksanaan Kawin Kontrak di Desa Tugu Selatan Kecamatan Cisarua Kabupaten Bogor}

Awal mula perkenalan wanita dan laki-laki pelaku kawin kontrak yaitu melalui orang yang membawa wanita tersebut kepada wisatawan Timur Tengah, jika orang Arab tersebut memang meminta dibawakan wanita. Jika tidak pun wanita-wanita tersebut sering datang menjajakan dirinya diantar oleh orang yang biasa mengantarnya. Orang-orang yang mengantarnya biasanya germo atau 
Sosietas Vol. 6 No.2, September 2016

tukang-tukang ojek dan driver yang biasa bekerja dengan wisatawan asing.

Proses pelaksanaan kawin kontrak itu sendiri tidaklah rumit, jika sudah pasti akan melakukan kawin kontrak, orang Arab tersebut harus datang ke kediaman keluarga pihak perempuan dan memastikan bahwa siapa keluarga perempuan tersebut. di luar itu semua wanita pelaku kawin kontrak biasanya memalsukan identitas keluarganya atau menyuruh orang lain berpura-pura menjadi keluarganya. Setelah itu dengan diantar oleh orang yang mengenalkan wanita tersebut, terjadilah kawin kontrak.

Pelaksanaannya tidak melalui lamaran, mereka langsung melaksanakannya di kediaman perempuan dengan wali saksi dan penghulu "seadanya". Biasanya yang menjadi penghulu, saksi dan wali hanyalah pura-pura saja, namun orang Arab tersebut tidak memperdulikan hal tersebut. Walaupun tidak ada proses lamaran, tapi tetap menggunakan mahar biasanya sejumlah uang tunai

Tidak ada yang menjadi syaratsyarat lain untuk dilangsungkannya kawin kontrak, tidak ada perjanjian secara tulisan melainkan secara lisan melalui kesepakatan kedua belah pihak tentang jangka waktu perkawinan. Tidak ada resepsi pernikahan dalam pelaksanaan kawin kontrak. Setelah selesai akad nikah, wanita barulah dibawa ke villa tempat orang Arab itu menetap.

\section{Konsekuensi Kawin Kontrak Terhadap Pemenuhan Kewajiban}

\section{Suami Isteri Pelaku Kawin Kontrak di Desa Tugu Selatan Kecamatan Cisarua Kabupaten Bogor}

Berdasarkan hasil penelitian bahwa tidak ada kewajiban dan hak yang khusus selayaknya suami isteri yang menikah secara sah. Setelah mereka melakukan ijab kabul dan dianggap menjadi pasangan suami isteri, benar-benar hak dan kewajiban mereka hanya seputar uang dan hubungan seks saja. Djuher (1983) menyatakan bahwa ada beberapa prinsip Agama Islam tentang perkawinan, diantaranya adalah:

Hak dan kewajiban suami isteri. Ikatan perkawinan menyebabkan timbulnya hak-hak dan kewajibankewajiban tertentu bagi pihakpihak yang terkait. Tak ubahnya seperti dalam suatu perikatan, di mana terdapat hak-hak dan kewajiban tertentu berupa suatu prestasi. Mengenai hak dan kewajiban suami isteri menurut Agama Islam ini dapat kiranya dikemukakan beberapa terjemahan ayat Al-Quran sebagai berikut:

1. Surat Al-Baqarah ayat 228 “...akan tetapi suami mempunyai tingkatan satu kelebihan dari pada isterinya..."

2. Surat An-Nisa ayat 34 "kaum lakilaki adalah pemimpin bagi kaum wanita, oleh karena Allah telah melebihkan kebahagiaan mereka (laki-laki) atas kebahagiaan yang lain (wanita) dan karena mereka (laki-laki) telah menafkahkan harta mereka". (hlm. 48)

Dalam penjelasan tersebut dijelaskan bahwa dalam setiap perkawinan akan menimbulkan hak-hak dan kewajiban tertentu, sedangkan dalam prakteknya 
tidak ada kewajiban tertentu dalam hubungan kawin kontrak selain bagi wanita wajib melayani kebutuhan seksual pasangannya hingga ia puas, dan bagi laki-laki harus membayar Sejumlah uang (mahar) sesuai dengan jangka waktu dan kesepakatan mereka. kemudian dalam ayat yang dikutip di atas mengatakan bahwa suami memiliki satu tingkat kelebihan dari pada isterinya, yang artinya adalah suami memiliki kewajiban lebih dalam rumah tangga yaitu memberikan nafkah, tidak hanya nafkah batin tapi juga nafkah berupa materi atau uang belanja, sedangkan dalam kawin kontrak suami tidak diwajibkan memberikan uang belanja pada isterinya, hanya memberikan uang kesepakatan yang dijadikan mahar ketika perkawinan saja.

Jika ada anak yang lahir dari kawin kontrak antara wanita lokal dengan laki-laki Timur Tengah, berdasarkan hasil penelitian, anak tersebut dibesarkan oleh ibunya dan tetap diberi nafkah oleh ayah biologisnya yaitu lakilaki Timur Tengah meskipun mereka telah kembali ke Negara asal mereka. Berbeda dengan pernyataan Haryono (2011) dalam jurnalnya yang mengatakan bahwa" ...berbeda dengan yang memiliki anak, harus menjadi single parent, di mana harus mengurus/menghidupi bayi yang dilahirkan karena hilangnya fungsi suami sebagai kepala keluarga yang menjadi sumber nafkah utama keluarga karena suami pulang ke negeri asal." (hlm. 3-4)

\section{Dampak Kawin Kontrak Bagi Pelaku Kawin Kontrak di Desa Tugu Selatan Kecamatan Cisarua Kabupaten Bogor}

Berdasarkan hasil penelitian, mereka juga sedikit demi sedikit bisa memenuhi kebutuhan tersier anggota keluarga mereka. hal tersebut berpengarahuh pada status sosial keluarga mereka di daerah asal mereka. Dari yang dulunya berasal dari keluarga miskin, kini semenjak ia menjadi pelaku kawin kontrak ia bisa membeli barang-barang kebutuhan tersier dan menjadikan status sosial keluarga adalah keluarga yang cukup. ada dampak positif yang dipengaruhi oleh hubungan kawin kontrak yang dilakukan wanita lokal dan orang Timur Tengah. wanita tuna susila yang biasa menjajakan diri mereka atau melakukan kawin kontrak dengan orang Arab rata-rata bisa berbahasa Arab dengan fasih walaupun tidak semua kata ia kuasai. itu artinya ada penyerapan-penyerapan nilai yang positif dalam bentuk budaya yang ditularkan laki-laki Timur Tengah pada wanita lokal. Hal ini berbeda dengan hasil penelitian Handoyo (2013) mengenai dampak kawin kontrak di Kota Jepara, yaitu:

Pernikahan dengan pria asing telah mengubah sistem nilai budaya para perempuan Jepara (isteri) kontrak, diantaranya: disiplin, efisien, tertutup, gila kerja, tidak suka ngerumpi, menghargai waktu, bicara seperlunya, tidak mau diganggu dan cenderung curiga kepada orang yang belum dikenalnya. (hlm. 242) 
Sedikitnya kawin kontrak membawa dampak positif dalam segi budaya bagi wanita lokal. Berdasarkan hasil penelitian bahwa sejauh ini informan tidak pernah mengalami kekerasan seksual dari laki-laki Timur Tengah, hanya saja mereka sering merasa kelelahan dalam berhubungan seksual. Ini menunjukkan bahwa adanya eksploitasi seksual terhadap wanita pelaku kawin kontrak yang dilakukan oleh laki-laki Timur Tengah. Hal ini tidak sesuai dengan Ariani (2014) dalam jurnalnya yang mengatakan bahwa:

Seorang perempuan sebagai pihak yang sederajat dengan lakilaki dapat menetapkan syaratsyarat yang diinginkan sebagaimana juga laki-laki, sehingga dalam perkawinan antara laki-laki, perempuan tidak terdapat kondisi yang mendominasi dan didominasi, semua pihak setara dan sederajat untuk saling bekerja sama dalam sebuah ikatan cinta dan kasih. (hlm. 76)

Dalam penjelasan tersebut dikatakan bahwa seorang perempuan memiliki derajat yang sama dengan laki-laki sehingga dalam perkawinan tidak ada pihak yang mendominasi ataupun didominasi. Sedangkan bagi pelaku laki-laki tidak ada dampak yang secara nyata dan langsung dirasakan oleh mereka.

\section{Pandangan Masyarakat Terhadap Kawin kontrak di Desa Tugu Selatan Kecamatan Cisarua Kabupaten Bogor}

Pandangan mengenai kawin kontrak ini terbagi ke dalam dua kelompok masyarakat, yakni masyarakat yang bekerja dengan turis Timur Tengah dan masyarakat yang tidak bekerja dengan turis Timur Tengah. masyarakat yang bekerja dengan Turis Timur Tengah cenderung menutupi keberadaan kawin kontrak karena mereka sendiri terlibat didalamnya. . Hasil penelitian tersebut sesuai dengan

Khalikin dan Fauziah (2011, hlm 896) yang mengatakan bahwa "praktik kawin kontrak dilakukan melalui calocalo atau oknum-oknum tertentu yang tempatnya terselubung tidak diketahui keberadaannya". Hal ini kebalikan dengan pendapat masyarakat yang tidak bekerja dengan orang Arab yang sangat menentang keberadaan kawin kontrak dan orang-orang Arab yang melakukan penyimpangan di daerah mereka.

\section{SIMPULAN}

Sebelum feomena kawin kontrak muncul, terlebih dahulu muncul daerah yang dinamakan Warung Kaleng atau lebih dikenal masyarakat Luar dengan sebutan Kampung Arab pada tahun 1980an. Setelah mulai banyak turis Timur Tengah yang datang ke Puncak. Pada tahun 1987 pertama kali muncul kawin kontrak yang dilakukan orang Arab dengan wanita lokal. Keberadaan kawin kontrak saat ini sifatnya tertutup dan sensitif karena jika sampai diketahui oleh yang berwajib akan dikenakan sanksi. Pandangan pelaku kawin kontrak sendiri terhadap pernikahan khususnya bagi wanita, mereka tetap menganggap pernikahan sesungguhnya adalah hal yang sakral 
Sosietas Vol. 6 No.2, September 2016 berbeda dengan kawin kontrak. Faktorfaktor pendorong wanita melakukan kawin kontrak yang utama adalah karena kebutuhan ekonomi dan harus berperan sebagai tulang punggung keluarga, sedangkan laki-laki melakukan kawin kontrak memang untuk memenuhi kebutuhan syahwatnya saja. Proses pelaksanaan kawin kontrak tidak berbelit-belit seperti melalui proses administrasi, yang penting ada calon mempelai dan sepakat atas mahar dan jangka waktu kawin kontrak. Dampak yang dirasakan bagi pelaku wanita lebih besar yaitu walaupun memang kebutuhan ekonomi terpenuhi tetapi mereka tidak bisa bersosialisasi dengan lingkungannya. Konsekuensi pemenuhan hak dan kewajiban suami isteri tidaklah berjalan dengan baik. jika mempunya anakpun, laki-laki tidak memiliki kewajiban untuk menafkahi anak tersebut. Pandangan masyarakat terbagi ke dalam dua pandangan di mana masyarakat $A$ merasa resah dengan adanya kawin kontrak sedangkan masyarakat B menganggap kawin kontrak tidak masalah.

\section{DAFTAR RUJUKAN}

\section{Buku:}

Anwar, Yesmil dan Andang. (2010). Kriminologi. Bandung: Refleksi Aditama.

Djuher, Z. (1983). Hukum Perkawinan Islam dan Relevansinya dengan Kesadaran Hukum Masyarakat Jakarta: Dewaruci Press.

Hamdani, Faisal M. (2008). Nikah
Mut'ah Analisis Perbandingan Hukum Antara Sunni \& Syiah. Jakarta: Gaya Media Pratama. Hilman, Hadikusuma. (2007). Hukum Perkawinan di Indonesia. Bandung: Mandar Maju.

Setiadi, Elly $M$ dan Kolip Usman. (2011). Pengantar Sosiologi. Jakarta: Kencana

Jurnal:

Ariani, Parida. 2014. Perlindungan Hukum Terhadap Hak-Hak Perempuan Studi Eksplorasi Tentang Fenomena Kawin Kontrak. Jurnal IImiah Universitas Mataram.

Handoyo, Eko dan Rohayuningsih, Heri. (2013). Kawin Kontrak: Latar Belakang, Keabsahan Hukum dan Dampaknya (Studi kasus di Kabupaten Jepara). Jurnal Forum IImu Sosial. Vol. 40 No. 2.

Haryono, Bagus. 2011. Kawin Kontrak di Indonesia: Fungsional Bagi Siapa?. Jurnal Sosiologi Dilema Dialektika Masyarakat. Vol 26 No. 1.

Ummanah, Pawennari Hijjang, dkk. 2015. The Tourist Contract Marriage In Cisarua Sub-District, Bogor Regency, West Java. International Journal Of Scientific \& Technology Research. Volume 4, Issue 02. Khalikin, Khalikin. F. 2011. Agama dan Budaya dalam Dinamika kehidupan masyarakat. Jurnal multikultural dan multireligius. Volume X No.4. 
Sosietas Vol. 6 No.2, September 2016

\section{Peraturan/Perundang-undangan}

Undang-undang Dasar Nomor.1 Tahun

1974 Tentang Perkawinan 